\title{
THE CONSUMER AS A SOURCE OF MARKETING INFORMATION IN THE INFORMATION SOCIETY
}

\section{Kamila Peszko ${ }^{1}$}

\begin{abstract}
The development of IT technology has provided people with free access to the Internet, which is now a place for consumers to look for opportunities to share their observations with others. The Internet user wants to be more aware, and willingly participates in the development of emerging brands. Companies have also found their place on the Internet, where they source information from Internet users. They realize the power of the consumer as a source of marketing information, and "take advantage" of consumer behavior to promote their brands. They analyze information about consumers, especially consumer preferences, and then publish this via social media in ways that might appeal to users and lead them to share it with others. This study describes this relationship between consumers and marketing via the Internet, and how the consumer is a source of marketing information, because of the possibilities created for entrepreneurs in the information society.
\end{abstract}

JEL Classification Numbers: M31, DOI: http://dx.doi.org/10.12955/cbup.v3.625

Keywords: costumer, social media, Internet

\section{Introduction}

The information society of the 21 st century has free access to information, but more importantly global access to a world of information available, through today's information and communication technology (ICT). Internet user communities can freely share their knowledge and preferences with others in their network. Social media enables people to establish new contacts, as well as facilitate communication with existing real-world friends. For companies, social media is primarily a huge marketing tool for growing their databases on consumers who use social networking sites like Facebook. It is a phenomenon involving intensive communication and entertainment, and has revolutionized companies' approaches to building brands. In addition, it has changed the behavior of its users significantly, as they demand more information about their favorite brands to "carry" the information further.

Facebook has shown that different types of social networking sites can serve as a platform for agreements that allow branding. Because of social media, it is now much easier to collect information about news, trends, offers, and initiatives (Ewolucja Social Media, 2014). In the same way "by word of mouth" distributed information, this cheaper form of communication provides a new space for marketers to reach their potential customers, i.e. through other Internet users. In this study, the author examines the role of marketers who are "fueling" the fire with information they control and conscious consumers called "prosumers" who are more or less aware of the tools in the hands of advertisers. Therefore, the aim of this study is to show how consumers are a source of marketing information in the information society, which created the possibilities for entrepreneurs. The research findings of studies carried out by various research organizations provide the theoretical background for this article.

\section{The consumer in the information society}

The information society is a culture of fast development and immediate distribution of information through modern communication technologies. The basic concept is to have practical information and free access to global information resources for all, through modern telecommunications networks. Importantly, the possibilities offered through the mass communication of information are open to everyone. European statistical data show that $74.8 \%$ of households had access to the Internet in Poland during 2014 (Central Statistical Office, 2014). This proportion was 2.9\% higher than that of the previous

\footnotetext{
${ }^{1}$ Kamila Peszko, Department of Marketing Service, University of Szczecin, Poland, kamila.peszko@wzieu.pl
} 
CBU INTERNATIONAL CONFERENCE ON INNOVATION, TECHNOLOGY TRANSFER AND EDUCATION

year. Though low compared to Europe overall, it still shows the steady growth and high potential of using the Internet as a source of information in Poland (Figure 1).

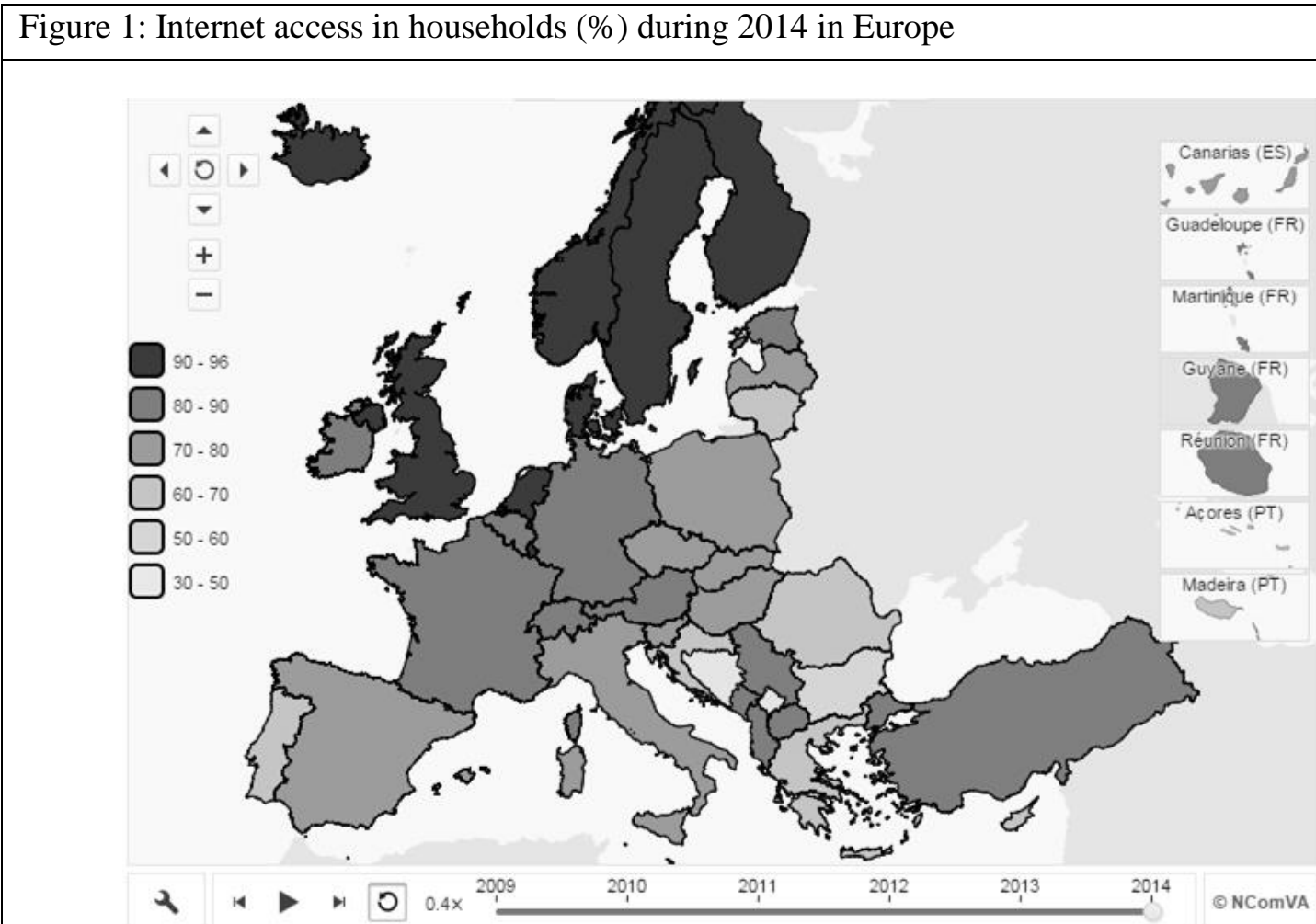

Source: Eurostat (n.d.)

Interestingly, West Europe Scandinavia and the United Kingdom had the highest levels of Internet access in households (Figure 1). The level of Internet access of enterprises in Europe was also high, with small increases over the past four years, reflecting the optimism in business regarding opportunities in the Internet society (Table 1).

\begin{tabular}{|c|c|c|c|c|c|}
\hline GEO/TIME & 2010 & 2011 & 2012 & 2013 & 2014 \\
\hline European Union ( 28 countries) & 94 & 95 & 95 & 96 & 97 \\
\hline Belgium & 97 & 96 & 97 & 97 & 97 \\
\hline Bulgaria & 85 & 87 & 87 & 89 & 91 \\
\hline Czech Republic & 95 & 96 & 97 & 96 & 98 \\
\hline Denmark & 97 & 98 & 99 & 99 & 99 \\
\hline Germany (until 1990 former territory of the FRG) & 97 & 97 & 97 & 98 & 98 \\
\hline Estonia & 96 & 96 & 96 & 97 & 96 \\
\hline Ireland & 92 & 93 & 94 & 95 & 98 \\
\hline Greece & 90 & 93 & 91 & 87 & 89 \\
\hline Spain & 97 & 97 & 96 & 97 & 98 \\
\hline France & 97 & 96 & 99 & 99 & 99 \\
\hline Croatia & 95 & 96 & 96 & 98 & 96 \\
\hline
\end{tabular}


CBU INTERNATIONAL CONFERENCE ON INNOVATION, TECHNOLOGY TRANSFER AND EDUCATION

MarCh 25-27, 2015, Prague, CZeCh Republic

WWW.CBUNI.CZ, OJS.JOURNALS.CZ

\begin{tabular}{|lrrrrr|}
\hline Italy & 94 & 94 & 96 & 97 & 98 \\
\hline Cyprus & 88 & 91 & 95 & 93 & 96 \\
\hline Latvia & 91 & 92 & 91 & 94 & 96 \\
\hline Lithuania & 96 & 98 & 100 & 100 & 100 \\
\hline Luxembourg & 96 & 97 & 98 & 98 & 100 \\
\hline Hungary & 90 & 89 & 89 & 88 & 88 \\
\hline Malta & 94 & 95 & 95 & 95 & 97 \\
\hline Netherlands & 98 & 100 & 100 & 100 & 100 \\
\hline Austria & 97 & 98 & 98 & 98 & 98 \\
\hline Poland & 96 & 94 & 93 & 94 & 93 \\
\hline Portugal & 94 & 95 & 95 & 96 & 97 \\
\hline Romania & 79 & 79 & 79 & 83 & 85 \\
\hline Slovenia & 97 & 97 & 98 & 97 & 98 \\
\hline Slovakia & 98 & 97 & 98 & 98 & 98 \\
\hline Finland & 100 & 100 & 100 & 100 & 100 \\
\hline Sweden & 96 & 96 & 98 & 98 & 98 \\
\hline United Kingdom & 91 & 95 & 94 & 96 & 95 \\
\hline Iceland & 98 & n/a & 99 & 99 & 100 \\
\hline Norway & 97 & 97 & 97 & 97 & 97 \\
\hline Former Yugoslav Republic of Macedonia, the & 84 & 82 & 88 & 92 & 93 \\
\hline Source Eur & & & & & \\
\hline
\end{tabular}

Source: Eurostat (n.d.)

Possibilities for online transactions arose with the development of the Internet, with many people purchasing products and services through this medium. This has been shown from surveys that identify the purchasing dependencies, psychological factors, and other characteristics of individuals. Effective marketing strategies include promotional activities, especially advertising, which in the modern world effectively manipulates and enhances the human benefits of a product, while minimizing its drawbacks.

The average consumer's behavior on the Internet largely depends on the marketing efforts, and their knowledge of communication and information tools. Customers know the aim of companies on the Internet is primarily to use information. Herbert Kubicek defines the information society as "a society in which individuals both as consumers and employees intensely and productively use information that becomes a resource" (Papińska-Kacperek, 2008, p. 18). The information society is fast acquiring more comprehensive information through use of the Internet, which helps people make decisions and therefore, it is important for this information to be reliable. Companies creating their own social media profiles have access to information that the customer voluntarily places, and businesses are increasingly using this information both for marketing and to establish cooperation with entrepreneurs and active consumers. The level of social media use by enterprises in 2013 and 2014 in Poland, for the varying sizes of enterprise, is presented in Figure 2. 


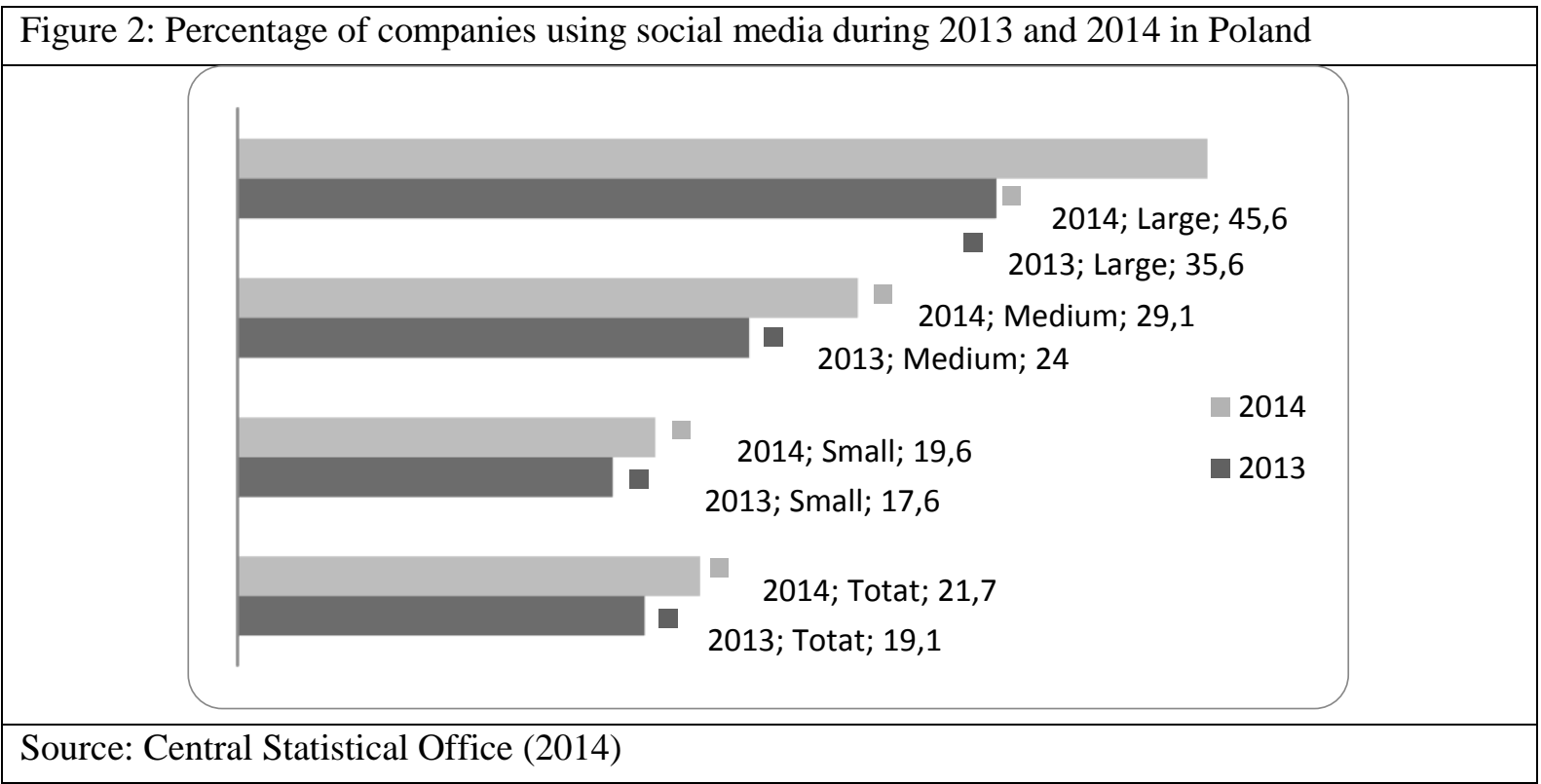

Approximately one-fifth of Poland's enterprises (21.7\%) used marketing opportunities through social media networking in 2014, compared to 30\% for Europe overall in 2013 (Central Statistical Office, 2014; Eurostat, n.d.).

Some companies in the EU encourage customers to create personal information profiles, to share and exchange experiences, opinions, information, and most of all, create communities of people with common interests around the enterprises' product brands, as indicated by EU social media statistics (Eurostat, n.d.). Online communities are repositories of knowledge about the customer, who plays a diverse role.

\section{The role of the consumer on the Internet}

Customers' behavior has changed and developed dynamically from the last half of the last century.. Modern technologies have played an important role in this process, particularly the Internet. Increasingly, interest continues to grow regarding the information published on the Internet in an era of information revolution (Scheibe, 2012). The consumer on the Internet approaches information in three ways: 1) searching, where they seek information on the Internet; 2) sharing, where they distribute information received from others; and 3) providing, where they create the message and make it available on the Internet for others), according to Scheibe (2012). An "e-consumer" defines a curious and active consumer using the Internet with modern electronic technology (Piekut, 2011). They are an "eprosumer" when they also consciously use this technology for deciding on purchases and proactively influence products and services available online (Piekut, 2011).

The Internet has promoted prosumption, with an increasing number of prosumers, i.e. consumers who promote products (or brands) or services available on websites, and who thus share their knowledge and observations with other consumers and producers (Domańska, 2009). A prosumer expects more personalized products, with interesting messages. They seek stimulating advertising that is sometimes fun rather, than the excess found through classical channels. Hence, many promoted brands depart from broadcasting of just content to more attractive forms in order to increase consumer interest. Marketers now deliver product information, novelties, and enhancements directly to consumers through the Internet to make buying decisions (Peszko, 2008; 2011). Because of the possibilities provided by modern telecommunications, a potential buyer is able to use their mobile device to access information anywhere as soon as it appears on the Internet. Many places on the Internet provide prosumers the opportunity to post their comments and opinions and then share these with others. There are already 
numerous prosumers involved, with more continuing to participate in active discussions (Wolny, 2013). The data on behavior of Internet users reveal a significant group of virtual opinion leaders emerging with strong influence and an ability to shape the shopping preferences of other Internet users. Marsden, Siejak (2010), from the London School of Economics claimed that it was from 10\% of opinion leaders depend on the choice of the remaining $90 \%$ of clients. Hence, marketers and agencies have a particular interest in reaching these opinion leaders (Siejak, 2010). Opinion leaders are not unlike other users, though they are usually young, well educated, and live in large cities (Mazurek, 2008). These virtual opinion leaders are also highly active people in the general community and operate in many environments in life outside of the Internet. They often start with commenting on articles in blogs and social networks on the Internet, and then engage in thematic groups and forums, becoming a virtual community leader as an expert or hobbyist (Mazurek, 2008).

Marketers, observing a decrease in the efficiency and confidence in classic advertising, investigated other options, including word of mouth marketing (WOMM) (Siejak, 2010). Rogers (1983) classified consumers into five categories by their tendency to acquire new assets, and provided these as the average percentage of the whole community (Siejak, 2010):

- innovators $(2.5 \%)$;

- opinion leaders or early adapters $(13.5 \%)$;

- early majority (34\%);

- late majority (34\%); and

- laggards or late adapters $(16 \%)$.

The results show that, where opinion leaders and early majority connect, is critical for marketing of the brand and successful uptake by consumers. On this basis, opinion leaders are important consumers and affect the success of a brand newly introduced into the market.

Siejak (2010) lists areas where opinion leaders naturally play an important role, in:

- marketing novelties, especially the new categories of products. e.g. Power Balance wristbands

- categories that aim at deep commitment from consumers, for instance, the Harley-Davidson brand, which has many customers wearing its logo as a tattoo; and product categories that are so complex, they require an education component to accompany the purchase; and

- categories of high trust, where consumers seek reliable and credible sources, e.g. the parenting industry, where expert mums, midwives, and doctors are often opinion leaders, other than from the sponsor of the brand for recommendations.

Other significant players that are active on the Internet include "wannabies" and professional bloggers, as distinguished in a study on cosmetic brands (Maison Research House, 2013). Wannabies are those who relish being liked and admired. This group feels the need to influence others, and therefore upload product recommendations. Their goal is to position themselves among the famous and recognized, who are "internauts." Hence, they often seek recommendations from professional bloggers and opinion leaders. The vast majority of company samples proceed directly to the wannabies, who generally have moderate influence on marketing a brand. In comparison, professional bloggers are mostly journalists, who are often hired as brand ambassadors and have a significant effect on the indicators of marketing performance on the Internet (Maison Research House, 2013).

A group, apart from the avowed and professional opinion leaders, involves the internauts, who use the Internet to support the marketing activities of companies. Their involvement relates to network information left behind from web searches for products. Many Internet users are vaguely aware of the consequences of their activities on the Internet. They seek information and solve their problems using 
the Internet, but leave traces of their activities in the form of "Cookies" (including Flash cookies), or details entered on their profiles on social networking sites. Online communities are viewed as involving people who are "good friends" that can help with decisions. Users involve communities in forums and newsgroups to search for advice from people who have previously purchased and recommend products. This often results in advertisements appearing with the search results, and many times the brand of a product or location appears related to an earlier Internet query or post.

Mobile devices are everyday accessories that are constantly recording information about the behavior of users, including shopping preferences and locations visited, in order for enterprises to deliver personalized advertisements. This originates from the data sent via the Internet, of both the macro-and microenvironment (customers and competitors). Statements on website forums, in groups, and mailing lists provide marketing information about the attitudes and preferences of the electronic community. Internet users on mailing lists and chatrooms, exchange opinions about products and services, and companies form opinions from these (Milic-Czerniak, 2011). Internet users write about their interests and complete online forms about their experiences, which may relate to their pet's favorite food or places they would like to visit. Users click on sponsored articles and advertisements appearing for stores, showing interest in the brand, and thus by sharing their preference they receive personalized advertising offers. Satisfied with the offers, they then share it with their friends and so become "sellers". Surveys conducted by K2 User Experience revealed $70 \%$ of respondents received marketing promotions from friends, while only $17 \%$ received such from sponsors of brands. Posts with hyperlinks strongly dominated the promotions (36\%), while every fifth was just text, and video and still images accounted for $18 \%$ and 15\%, respectively (Makuch, 2014). This shows the extent of people's desire to share information.. Only $4 \%$ of respondents were aware that companies, they buy from, track and analyze their Internet activities to base their promotions. In addition, such consumers accept these practices when they are part of the exchange, i.e. when they receive benefits for sharing the data. Customer groups are displaying an increasing rate of readiness to cooperate rate each year, e.g. $45 \%$ of the global population in 2011, and 59\% in 2014 (McCann Truth Central, 2014). Nonetheless, most customers are concerned about excessive use of their personal data in dependence algorithms (Big Data) with $71 \%$ of people worried about the amount of information stored about them (McCann Truth Central, 2014).

\section{Conclusion}

The information revolution, at the turn of the 20th century, caused significant changes in the relationship between businesses and consumers. The new technical and technological solutions provided greater access to new possibilities for obtaining information. Companies no longer focus purely on soliciting groups of customers to succeed, but now realize the variety of consumers and new market opportunities in the information society. This now is about two-way communication with the consumer, based on consumer feedback with active dialogue concerning consumer requirements and preferences (Maciejewski, 2012). Thanks to modern technology, information delivery and communication has become instant, with consumers more open to talk about their needs and take part in shaping the goods for their ideal product. The Internet is a source of information that has led to a change in the role of the consumer. Companies now perceive and recognize the benefits derived from such a source of communication, which on one hand provides simple access to consumer information, and on the other hand, easier and more reliable messaging about their product or brand. However, consumer awareness of the source of information for recommending a brand or product, and setting their boundaries in terms of privacy in the transmission of information remains important. 


\section{References}

Central Statistical Office (2014). Społeczeństwo informacyjne w Polsce [Information Society in Poland]. Warsaw: Author. Retrieved from: http://stat.gov.pl/obszary-tematyczne/nauka-i-technika-spoleczenstwo-informacyjne/spoleczenstwoinformacyjne.

Domańska, K. (2009). Kim jest prosument [What is a prosumer], Marketing w Praktyce [Marketing in Practice], 29, 35-38.

Eurostat. (n.d.). Information society statistics. Retrieved from http://ec.europa.eu/eurostat/web/informationsociety/data/database.

Ewolucja Social Media. (2014). Retrieved July 2, 2014, from http://www.atom.lodz.pl/epr/ewolucja-social-media.

Maciejewski, G. (2012). Konsument w strategii współczesnego przedsiębiorstwa [Consumer modern enterprise strategy]. Konsumpcja i Rozwój [Consumption and Development],2. 37-46.

Maison Research House. (2013, March 7). Jak wywrzé́ wpływ na opinie internautów w kontekście marek kosmetycznych [How to influence the opinions of Internet users in the context of cosmetic brands]. Retrieved from http://nowymarketing.pl/ a/1214,jak-wywrzec-wplyw-na-opinie-internautow-w-kontekscie-marek-kosmetycznych-infografika.

Makuch, P. (2011). Jak konsumujemy posty znajomych i marek na Facebook’u? Eye tracking stron głównych użytkowników i fan pages marek [How do we consume posts friends and brands on Facebook? Eye tracking user home pages and fan pages brands]. Retrieved from http://www.k2.pl/_files/K2_UserExperience_Facebook_Eyetracking.pdf.

McCann Truth Central (2014, October 6) Kupujacy w Internecie godza się na bycie śledzonym, choć sq tym zaniepokojeni [Buyer on the Internet consent to being tracked, although they are the concerned]. Retrieved from: $\mathrm{http}: / / \mathrm{www}$.wirtualnemedia.pl/artykul/kupujacy-w-internecie-godza-sie-na-bycie-sledzonym-choc-sa-tym-zaniepokojeni.

Mazurek, G. (2008 ). Blogi i wirtualne społeczności - wykorzystywanie w marketingu [Blogs and virtual communities - using marketing]. Kraków: Wolters Kluwer Polska.

Milic-Czerniak, R. (2011). Nowoczesne technologie w systemach informacji marketingowej [Modern technologies of marketing information systems]. In M. G. Wozniak \& C. F. Hales (Ed.), Nierówności społeczne a wzrost gospodarczy. Społeczeństwo informacyjne - regionalne aspekty rozwoju [Social inequality and economic growth. Information society regional development issues] (pp. 148-160). Rzeszów: Wydawnictwo Uniwersytetu Rzeszowskiego.

Papińska-Kacperek, J. (2008). Społeczeństwo informacyjne [Information society], Warszawa: Wydawnictwo Naukowe PWN.

Piekut, M. (2011). Konsumenci korzystający z usług elektronicznych Consumers using electronic services]. Wiadomości Statystyczne [News Statistics], 10, 82-94.

Peszko, K. (2008). Guerrilla marketing czyli niekonwencjonalne działania marketingowe w dobie prosumenta [Guerrilla marketing that is unconventional marketing in the age of prosumer]. In G. Rosa, \& A. Smalec, (Ed.), Qou Vadis Marketingu; Nowoczesna komunikacja a zachowania konsumentów, s.93 [Marketing; Modern communication and consumer behavior: conference materials, Szczecins, 93]. China: Wydawnictwo Zapol.

Peszko K. (2011): Instrumenty marketingu i ich wpływ na zachowania nabywców [Marketing instruments and their impact on the behavior of buyers]. In G. Rosa \& J. Perenc (Ed.), Zachowania nabywców [Behavior of buyers]. Szczecin: Science, University of Szczecin.

Scheibe, A. (2012). Czynniki warunkujące wpływ informacji nieformalnych rozpowszechnianych za pośrednictwem Internetu na decyzje zakupowe [Factors determining the impact of informal information disseminated via the Internet on purchasing decisions]. Zarzadzanie i Finanse [Management and Finance], 4(2) 230-232.

Rogers, E. M. (1983). Diffusion of Innovations. New York: The Free Press.

Siejak, M. (2010, October). Liderzy opinii filar efektywnej rekomendacji [Opinion leaders pillar of effective recommendations]. Marketing $w$ praktyce [Marketing in practice]. Retrieved from http://6ix.pl/pg/85/liderzy-opinii$\% \mathrm{E} 2 \% 80 \% 93$-filar-efektywnej-rekomendacji.

Wolny, R. (2013). Prosumpcja i prosumpcjonizm na rynku e-usług [Prosumption and prosumer on the e-services], Konsumpcja i rozwój [Consumption and Development], 1, 152-163. 